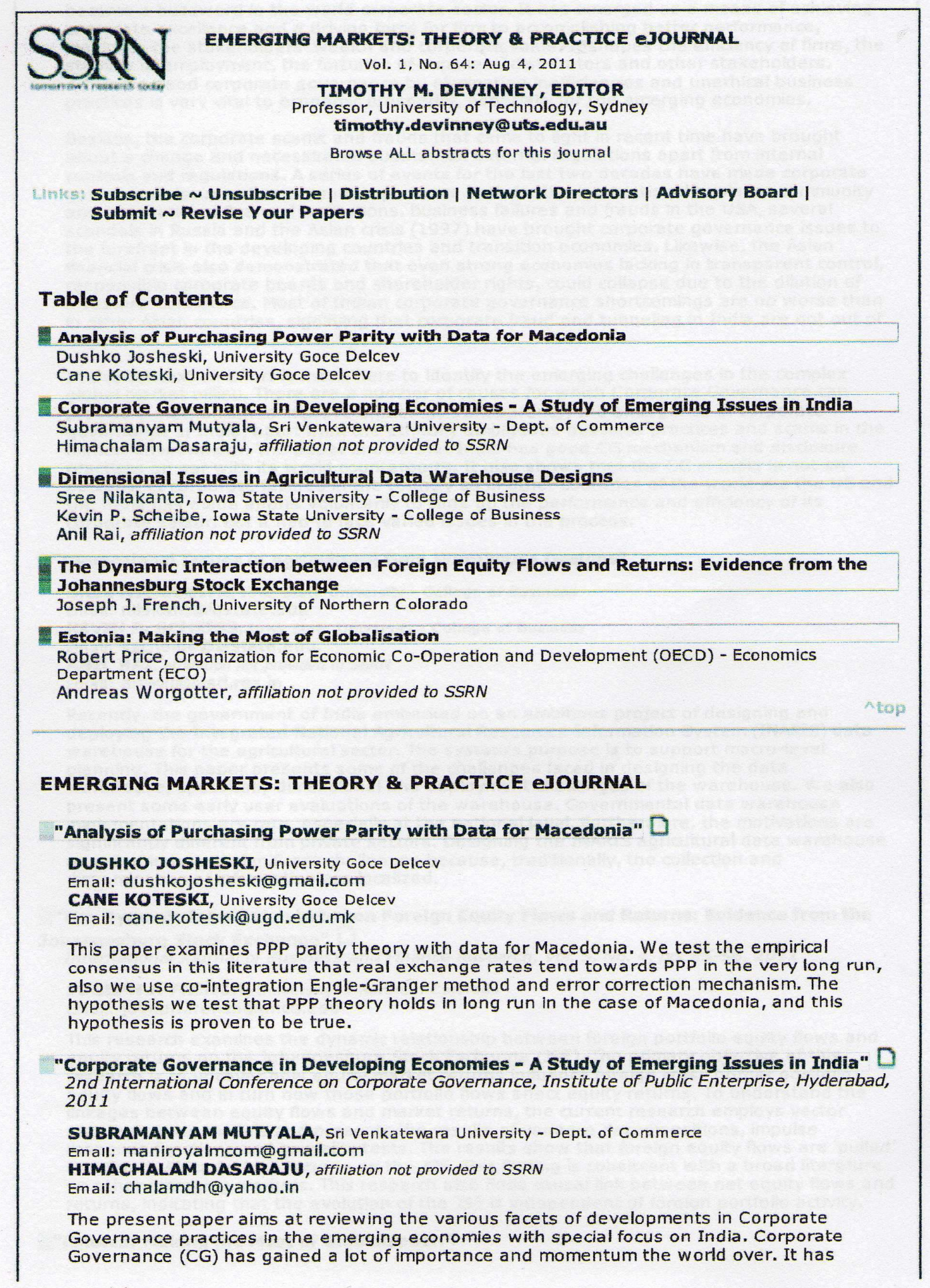




\section{OYD T INTERNATIONAL FINANCE JOURNAL \\ Vol. 3, No. 120: Jul 19, 2011 \\ Brouse ALL abstracts for this journal \\ Link s Subscribe $\sim$ Unsubscribe | Distribution | Network Directors | Advisory Board | Submit Revise Your Papers}

\section{Table of Contents}

Foreign Exchange Determination in Ghana

John E. Baiden, Central University College

Small Lessons from the Recent Euro-Dollar Skirmishes

Dino Martellato, Ca Foscari University of Venice - Department of Economics

Global and Regional Spillovers to GCC Equity Markets

Oral H. Williams, International Monetary Fund (IMF)

Tahsin Saadi-Sedik, International Monetary Fund (IMF)

Currency Jumps, Cojumps and Trading Profits: Role of Macroeconomic Announcements Arjun Chatrath, University of Portland - Dr. Robert B. Pamplin, Jr. School of Business Administration Ryan Dailing, Pyxis Global Financial Services

Hong Miao, Colorado State University - Department of Finance \& Real Estate

Sanjay Ramchander, Colorado State University - Department of Finance \& Real Estate

The Effects of Talwan Direct Investment in China on Taiwan

Lawrence Wang, affiliation not provided to SSRN

Forecasting FOREX Volatility in Turbulent Times

Rajesh Mohnot, affiliation not provided to SSRN

Analysis of Purchasing Power Parity with Data for Macedonia

Dushko Josheski, University Goce Delcev

Cane Koteski, University Goce Delcev

Evidence on the Performance of Country Index Funds in Global Financial Crisis

Ilhan Meric, Rider University

Christine Lentz, Rider University

Wayne Smeltz, Rider University

Gulser Meric, Rowan University - Accounting \& Finance

The Effects of Short-Term Interest Rates on Output, Price and Exchange Rates: Recent Evidence from China

Shuzhang Sun, Lincoln University (NZ)

Christopher Gan, Lincoln University (NZ)

Baiding $\mathrm{Hu}$, Lincoln University (NZ)

Relationships Among Foreign Institutional Investments, Stock Returns and Currency Change-Over Rates in India

Subrata Kumar Mitra, Institute of Management Technology (IMT)

\section{INTERNATIONAL FINANCE EJOURNAL}

"Foreign Exchange Determination in Ghana" 0

JOHN E. BAIDEN, Central University College

Email: jbaidenus@yahoo.com

In Ghana, most of the time imports exceed exports, so the demand for foreign exchange

(dollar) always exceeds supply and this puts intense upward pressure on the exchange rate.

There has been continuous depreciation of the cedi against most of the major currencies

especially the US dollar, which is largely use for commercial transactions. Since the demand

for dollar most of the time exceeding supply, international dollar values seldom have impacts 


\section{STRATEGY \& MACROECONOMIC POLICY EJOURNAL}

Vol. 3, No. 28: Jul 18, 2011

Browse ALL abstracts for this journal

Livks: Subscribe Unsubscribe | Distribution | Network Directors |

Submit $\sim$ Revise Your Papers

\section{Table of Contents}

The Offshoring Relationship

Rachel Ang, affiliation not provided to SSRN

Analysis of Purchasing Power Parity with Data for Macedonia

Dushko Josheski, University Goce Delcev

Cane Koteski, University Goce Delcev

Local Immiaration Prosecution: A Study of Arizona Before SB 1070

Ingrid V. Eagly, University of California, Los Angeles (UCLA) - School of Law

Revisiting a School of Military Government: How Reanimating a World War II-Era Institution Could Professionalize Military Nation Building

Rebecca Patterson, Ewing Marion Kauffman Foundation

A Comment on 'Towards an Economic Theory of Methodology'

Walter E. Block, Loyola University New Orleans - Joseph A. Butt, S.J. College of Business

\section{STRATEGY \& MACROECONOMIC POLICY EJOURNAL}

\section{"The Offshoring Relationship"}

RACHEL ANG, affiliation not provided to SSRN

Email: rachel.ang@msn.com

Offshoring is becoming increasing prominent. Corporations are using offshoring as the key business strategy to ensure growth and competitiveness (Snieska \& Draksaite, 2007).

Corporate partnership is often compared to the partnership of a marrlage. This relationship is evidenced by gained in market share, new market values, a wider range of product offerings, control over the supply chain, and improved operational and cost effectiveness and efficiencies. However, past studies revealed that $50 \%$ of the marriage resulted in divorce (Jiang \& Qureshi, 2005). The study aligned a comprehensive "insurance" risk assessment to assist corporations with the success of their marriage relationships.

\section{"Analysis of Purchasing Power Parity with Data for Macedonia"}

DUSHKO JOSHESKI, University Goce Delcev

Email: dushkojosheski@gmail.com

CANE KOTESKI, University Goce Delcev

Email: cane.koteski@ugd.edu.mk

This paper examines PPP parity theory with data for Macedonia. We test the empirical consensus in this literature that real exchange rates tend towards PPP in the very long run, also we use co-integration Engle-Granger method and error correction mechanism. The hypothesis we test that PPP theory holds in long run in the case of Macedonia, and this hypothesis is proven to be true.

"Local Immigration Prosecution: A Study of Arizona Before SB 1070"

UCLA Law Review, Vol. 58, 2011

UCLA School of Law Research Paper No. 11-21

INGRID V. EAGLY, University of California, Los Angeles (UCLA) - School of Law Email: eagly@law.ucla.edu 


\title{
Analysis of Purchasing power parity with data for Macedonia
}

\author{
Msc Dushko Josheski \\ dusko.josevski@ugd.edu.mk \\ Ph.D Cane Koteski \\ cane.koteski@ugd.edu.mk
}

\begin{abstract}
$\underline{\text { Abstract }}$
This paper examines PPP parity theory with data for Macedonia. We test the empirical consensus in this literature that real exchange rates tend towards PPP in the very long run, also we use co-integration Engle-Granger method and error correction mechanism. The hypothesis we test that PPP theory holds in long run in the case of Macedonia, and this hypothesis is proven to be true.
\end{abstract}

Key words : PPP, Exchange rate, Co-integration, unit root, stationarity

\section{$\underline{\text { Introduction }}$}

The theory of purchasing power parity (PPP) constitutes one of the basic elements of exchange rate determination.In the case of absolute PPP the exchange rate equals the relative price levels between the countries, whereas in the case of relative PPP the exchange rate movement equals the difference between the relative price level shifts (Boršič,Beko, Kavkler,).

The purchasing power parity theory uses long run equilibrium exchange rate of two currencies to equalize their purchasing power. This theory is developed by Gustav Kassel in 1920, and it is based on the law of one price. This theory states that commodity in two different locations should have same price, regardless of the locations (Zheng, 2009). While few economists take PPP seriously as short-term proposition, they believe in purchasing power parity as an anchor for long run exchange rate (Rogof, 1996). Empirical literature in this field has established consensus on a few facts. First, real exchange rates (nominal adjusted for inflation) tend towards purchasing power parity in the long run. This is the hypothesis we set here and we are going to test later with Macedonian data. Second, short run deviations from purchasing power parity are large and volatile. Balasa Samuelson effect also is one of the most well known channels through which real convergence leads to higher inflation rates. 
According to this concept, higher productivity growth in the sector of tradable goods, contrary to non-tradable goods sector of one country, will lead to positive inflatory differential and will lead to real appreciation-through the price growth of non-tradable goods on the market(Bogoev,2008) .Following relative PPP, the movements in nominal exchange rates are expected to compensate for price level shifts. So, the real exchange rate should be constant over long-run and their time series should be stationary (Parikh and Wakerly 2000). This is part or a whole second hypothesis that we are testing here. Real exchange rates are calculated from nominal using CPI's:

$$
\mathrm{RE}_{\mathrm{t}}=\mathrm{E}_{\mathrm{t}}\left(\mathrm{P}_{\mathrm{t}}^{*} / \mathrm{P}_{\mathrm{t}}\right)
$$

where $\mathrm{RE}_{\mathrm{t}}$ stands for the real exchange rate, $\mathrm{E}_{\mathrm{t}}$ is the price of a foreign currency in units of the domestic currency, and $\mathrm{P}_{\mathrm{t}}^{*}$ and $\mathrm{P}_{\mathrm{t}}$ represent the foreign price index and the domestic price index(Boršič,Beko, Kavkler, ).If we take logarithms of both sides we get

$$
\log \left(\mathrm{RE}_{\mathrm{t}}\right)=\log \left(\mathrm{E}_{\mathrm{t}}\right)+\log \left(\mathrm{P}_{\mathrm{t}}^{*}\right)-\log \left(\mathrm{P}_{\mathrm{t}}\right)
$$

With the log-log arrangement of the equation we can estimate the elasticities, while with first difference the relative growth of the variables. On the next graph it is plotted natural logarithm of exchange rate variable.

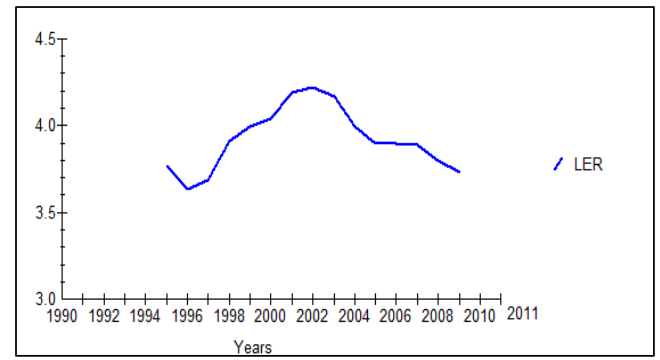

Relative instability of the exchange rate movements in transitional countries (Macedonia is in this group of countries) is in the literature explained by inherited macroeconomic imbalances in transition countries, mixed performance of chosen exchange rate arrangements, and the process of catching up with developed economies(Egert, et al 2006).As in neo-keynesian tradition exchange rate is one of the transmissions channels in the economy through which monetary policy can influence the inflation in the economy and the output gap (Besimi, 2006). Purchasing power parity (PPP) adjusted for the Balassa-Samuelson (BS) effect is expected to hold in the long-run in a small and open economy (Besimi, 2006). 


\section{Time series analysis for Purchasing power parity of Macedonia ${ }^{1}$}

One of the main tasks in time series analysis is to make conclusions about number of unit roots in a given time series. That way we are making conclusions whether time series is stationary or it has such a non stationary which is removed by differencing.

Most popular tests of unit root are D-F and ADF tests .Next table simulates the idea of the models

\begin{tabular}{|c|c|}
\hline Autoregressive model AR(1) & Hypothesis \\
\hline 1. $X_{t}=\phi_{0}+\phi_{1} X_{t-1}+\varepsilon_{t}$ & $H_{0}: \phi_{1}=1 \Rightarrow$ unit root \\
& $H_{1}: \phi_{1}<1 \Rightarrow$ Stationary \\
\hline$X_{t}=\phi_{0}+\phi_{1} t+\phi_{1} X_{t-1}+\varepsilon_{t}$ & $H_{0}: \phi_{1}=1 \Rightarrow$ unit root \\
& $\Rightarrow$ Unit root with a drift \\
\hline
\end{tabular}

Next we are estimating DW value from Model 1 like

$\tau=\frac{\hat{\phi}_{1}-1}{s(\hat{\phi})}$ where $s(\hat{\phi})$ is the standard error of the coefficient (model with constant)

And from the second model (model with constant and a trend) $\tau_{t}=\frac{\hat{\phi}_{1}-1}{s(\hat{\phi})}$

Critical values for comparison we are determining for a given sample $\mathrm{T}$

\begin{tabular}{|l|l|l|}
\hline Type DF test & Level of significance 5\% & Level of significance $10 \%$ \\
\hline$\tau$ & $\tau^{t}=-2.8621-2.738 / T$ & $\tau^{t}=-2.5671-1.438 / T-4.48 T^{2}$ \\
\hline$\tau_{t}$ & $\tau_{t}^{t}=-3.4126-4.039 / T-17.83 T^{2}$ & $\tau_{t}^{t}=-3.1279-2.418 / T-7.58 T^{2}$ \\
\hline
\end{tabular}

\footnotetext{
${ }^{1}$ See Appendix 1 definitions of the variables
} 
In our analysis we use PPP one country's relative price / US price level and CPI indices, trade as percentage to GDP and Exchange rate (local currency relative to US dollar), and the first difference of the logarithms of these series approximates their growth rates.

\section{Testing for unit roots}

Graphic tests showed that LNPPP and DLNPPP are non-stationary; also ADF test showed that we cannot reject the null hypothesis of unit root, also LER and DLER are non-stationary and we cannot reject the null hypothesis of unit root. We use DF test because it has highest info criteria. $^{2}$

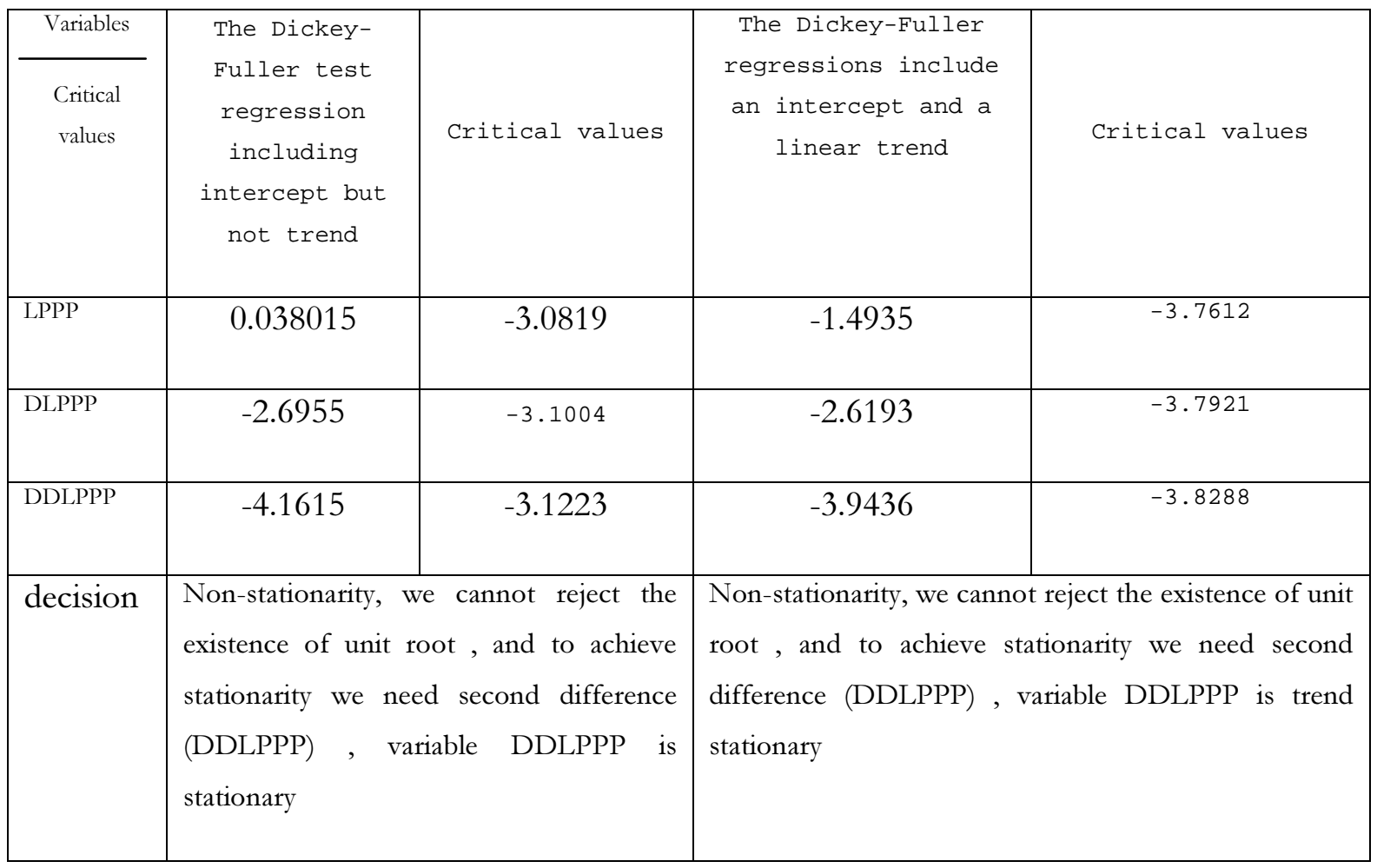

Next, follows a graphical presentation of these variables
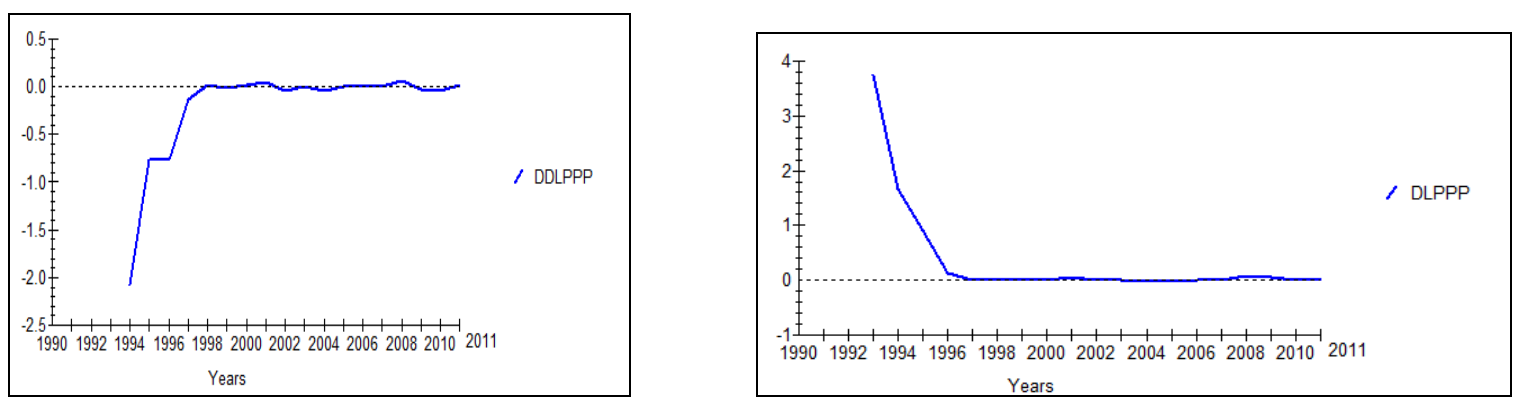

\footnotetext{
${ }^{2}$ See Appendix 2 Unit root testing
} 


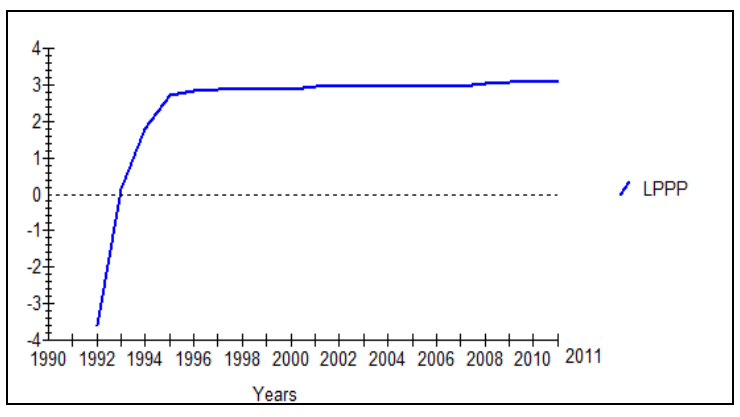

\section{Co-integration Engle Granger method for Macedonia}

Engle-Granger method for cointegration, implies a check if the residuals of the cointegrating regression are stationary ${ }^{3}$.

The estimated equation is:

$$
\begin{array}{ccc}
D L \hat{E} R= & 0.0086 & -0.41 D L P P P \\
\mathrm{p}= & {[.816]} & {[.602]}
\end{array}
$$

Intercept is in the regression because it ensures that error term has zero mean and it is included for statistical purposes only. Dropping the intercept will result in upward biased t-statistics and will lead to incorrect conclusion that certain coefficients are statistically significant. A DLER variable is first difference of natural logarithm of exchange rate. If DLPPP or first difference of the $\log$ of relative inflation increases by $1 \%$ on average the ER will result in downward change (depreciation) by $0.41 \%$. Unit root test of the residuals from this regression shows that estimated values have less negative value than critical values so that test shows that there exist no long run relationship between this variables .Estimated value -1.4920 is higher than critical value -4.1109 (see Appendix 3 Engle Granger co-integration method).

\section{Error correction mechanism ${ }^{4}$}

The short run relationship between variables is captured by the coefficient of the independent variable, whereas the adjustment toward the long run equilibrium is given by the coefficients of the EC mechanism (Harris, Sollis, 2003). ECM use second differences of these variables as they appear to be stationary.

\footnotetext{
${ }^{3}$ See Appendix 3 Engle Granger co-integration method

${ }^{4}$ See Appendix 4 Error correction mechanism
} 


\section{$D D L \hat{E} R=-0.0052+0.297 \mathrm{DDLPPP}+0.50958 \mathrm{u}_{\mathrm{t}-1}$}

$$
\mathrm{p}=\quad[.860] \quad[.653] \quad[.088]
$$

In the short run, $1 \%$ relative change will influence change in ER by $0.29 \%$, while in the long run $50,95 \%$ of the disequilibrium in the last year between change in ER and inflation will be eliminated in the current year. Short run coefficient is insignificant while long run coefficient is significant. According to the next Table model is well specified.

\begin{tabular}{|l|c|l|}
\hline Hypothesis & \multicolumn{1}{|c|}{$\begin{array}{c}\text { p-value of } \\
\text { the test }\end{array}$} & Decision \\
\hline $\mathrm{H}_{0}$ : No residual correlation & {$[.080]$} & $\begin{array}{l}\text { Insufficient evidence to reject } \\
\mathrm{H}_{0} \text { at } 1,5 \% \\
\text { level of significance }\end{array}$ \\
\hline $\begin{array}{l}\mathrm{H}_{0}: \text { Linear relationship between } \\
\text { variables }\end{array}$ & {$[.906]$} & $\begin{array}{l}\text { Insufficient evidence to reject } \\
\mathrm{H}_{0} \text { at } 1,5 \text { and } 10 \% \\
\text { level of significance }\end{array}$ \\
\hline $\mathrm{H}_{0}:$ Normality in residuals & {$[.703]$} & $\begin{array}{l}\text { Insufficient evidence to reject } \\
\mathrm{H}_{0} \text { at } 1,5 \text { and } 10 \% \\
\text { level of significance }\end{array}$ \\
\hline $\mathrm{H}_{0}:$ Homoskedasticity & {$[.287]$} & $\begin{array}{l}\text { Insufficient evidence to reject } \\
\mathrm{H}_{0} \text { at } 1,5 \text { and } 10 \% \\
\text { level of significance }\end{array}$ \\
\hline
\end{tabular}

In order to test for parameter stability we perform CUSUM and CUSUMSQ plots are examined

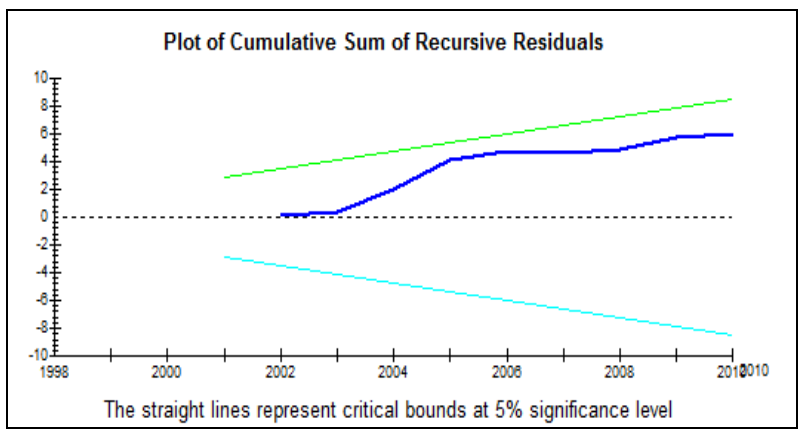




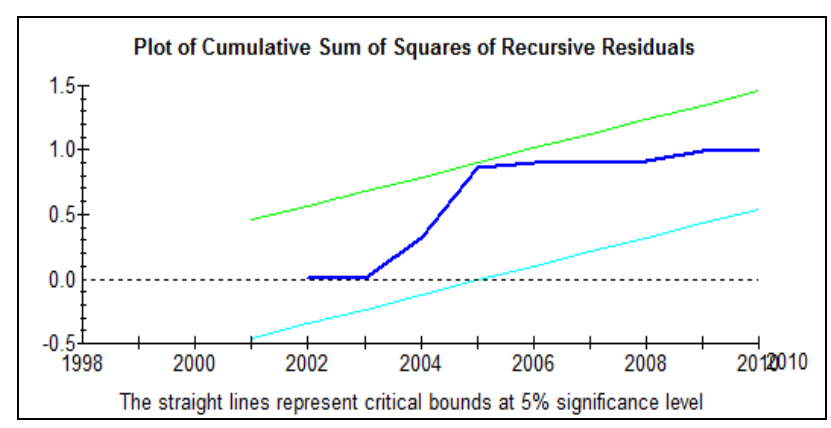

According to CUSUM and CUSUM square there are no structural breaks.

As the variable DDLPPP is not statistically significant, this is consistent with Rogoff (1996), who states that PPP does not hold in long run. So we can rewrite the model and estimate as follows

$$
\begin{aligned}
& D D L \hat{E} R=-0.0072+0.515 \mathrm{u}_{\mathrm{t}-1} \\
& \mathrm{p}=\quad[.798] \quad[.072]
\end{aligned}
$$

This model suggests that on average $51,5 \%$ of the departure of ER from its equilibrium level will be offset in the next period. In summary model provides some evidence of long run PPP. and trade \% GDP. 


\section{Appendices}

\section{Appendix 1}

\begin{tabular}{|l|l|}
\hline PPP & $\begin{array}{l}\text { Purchasing power parity conversion factor is the } \\
\text { number of units of a country's currency required to buy } \\
\text { the same amounts of goods and services in the domestic } \\
\text { market as U.S. dollar would buy in the United States. } \\
\text { This conversion factor is for GDP. }\end{array}$ \\
\hline ER- & $\begin{array}{l}\text { Official exchange rate refers to the exchange rate } \\
\text { determined by national authorities or to the rate } \\
\text { determined in the legally sanctioned exchange market. It } \\
\text { is calculated as an annual average based on monthly } \\
\text { averages (local currency units relative to the U.S. dollar }\end{array}$ \\
\hline DLER & $\begin{array}{l}\text { First difference of the natural logarithm of the exchange } \\
\text { rate }\end{array}$ \\
\hline DLPPP & $\begin{array}{l}\text { First difference of the natural logarithm of Purchasing } \\
\text { power parity }\end{array}$ \\
\hline DDLER & $\begin{array}{l}\text { Second difference of the natural logarithm of the } \\
\text { exchange rate }\end{array}$ \\
\hline plecond of the natural logarithm of Purchasing power
\end{tabular}

\section{Appendix 2 Unit root testing}

Unit root testing for LPPP and DLPPP and DDLPPP

Unit root tests for variable LPPP

The Dickey-Fuller regressions include an intercept but not a trend

15 observations used in the estimation of all ADF regressions.

Sample period from 1997 to 2011

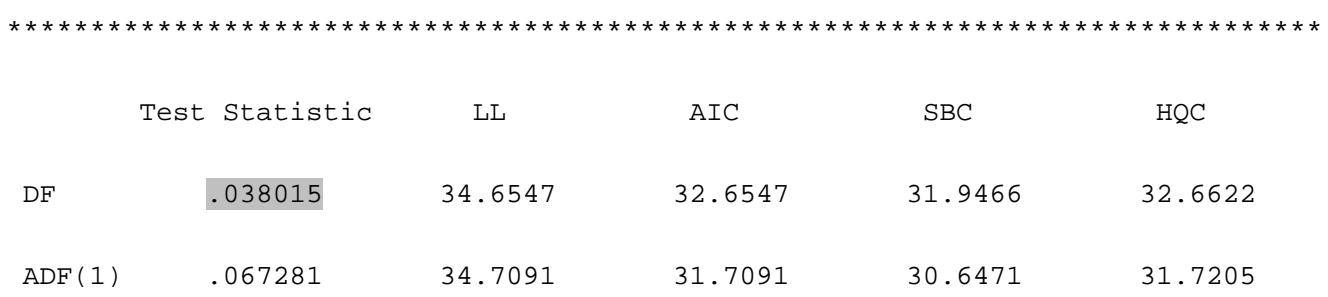




$\begin{array}{llllll}\operatorname{ADF}(2) & -.43206 & 35.3861 & 31.3861 & 29.9700 & 31.4012 \\ \operatorname{ADF}(3) & -.30587 & 35.4000 & 30.4000 & 28.6298 & 30.4188 \\ \operatorname{ADF}(4) & -.77801 & 36.0766 & 30.0766 & 27.9525 & 30.0992\end{array}$

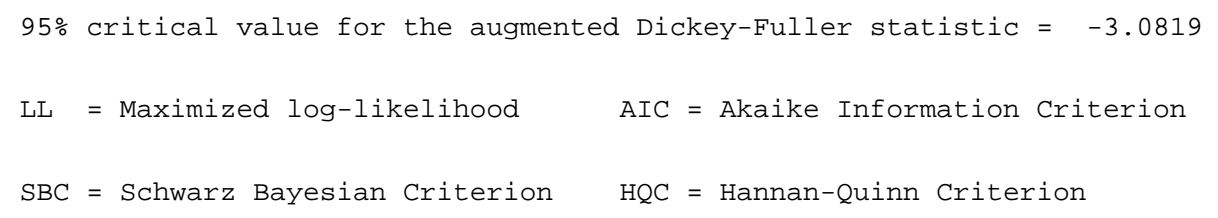

\begin{tabular}{|c|c|c|c|c|c|}
\hline & Test Statistic & LL & AIC & SBC & $\mathrm{HQC}$ \\
\hline $\mathrm{DF}$ & -1.4935 & 36.1490 & 33.1490 & 32.0869 & 33.1603 \\
\hline $\operatorname{ADF}(1)$ & -1.7773 & 36.8930 & 32.8930 & 31.4769 & 32.9081 \\
\hline $\operatorname{ADF}(2)$ & -2.0534 & 37.9612 & 32.9612 & 31.1911 & 32.9801 \\
\hline $\operatorname{ADF}(3)$ & -1.9430 & 38.1421 & 32.1421 & 30.0180 & 32.1648 \\
\hline $\operatorname{ADF}(4)$ & -2.1416 & 39.0251 & 32.0251 & 29.5469 & 32.0515 \\
\hline
\end{tabular}

95\% critical value for the augmented Dickey-Fuller statistic $=-3.7612$

LL = Maximized log-likelihood AIC = Akaike Information Criterion

$\mathrm{SBC}=$ Schwarz Bayesian Criterion $\quad \mathrm{HQC}=$ Hannan-Quinn Criterion

unit root tests for variable DLPPP

The Dickey-Fuller regressions include an intercept but not a trend

14 observations used in the estimation of all ADF regressions.

Sample period from 1998 to 2011 


$\begin{array}{lccccc} & \text { Test Statistic } & \text { LL } & \text { AIC } & \text { SBC } & \text { HQC } \\ \text { DF } & -2.6955 & 32.3708 & 30.3708 & 29.7317 & 30.4300 \\ \operatorname{ADF}(1) & -2.4205 & 32.4282 & 29.4282 & 28.4696 & 29.5169 \\ \operatorname{ADF}(2) & -2.3438 & 32.5517 & 28.5517 & 27.2736 & 28.6700 \\ \operatorname{ADF}(3) & -2.3351 & 32.9825 & 27.9825 & 26.3848 & 28.1304 \\ \operatorname{ADF}(4) & -2.3262 & 33.4397 & 27.4397 & 25.5226 & 27.6172\end{array}$

95\% critical value for the augmented Dickey-Fuller statistic $=-3.1004$

LL = Maximized log-likelihood AIC = Akaike Information Criterion

$\mathrm{SBC}=$ Schwarz Bayesian Criterion $\quad$ HQC $=$ Hannan-Quinn Criterion

Unit root tests for variable DLPPP

The Dickey-Fuller regressions include an intercept and a linear trend

14 observations used in the estimation of all ADF regressions.

Sample period from 1998 to 2011

\begin{tabular}{|c|c|c|c|c|c|}
\hline & Test Statistic & LL & AIC & SBC & $\mathrm{HQC}$ \\
\hline $\mathrm{DF}$ & -2.6193 & 32.4519 & 29.4519 & 28.4933 & 29.5406 \\
\hline $\operatorname{ADF}(1)$ & -2.3274 & 32.4853 & 28.4853 & 27.2072 & 28.6036 \\
\hline $\operatorname{ADF}(2)$ & -2.3348 & 32.8026 & 27.8026 & 26.2049 & 27.9505 \\
\hline $\operatorname{ADF}(3)$ & -2.2049 & 33.0317 & 27.0317 & 25.1145 & 27.2092 \\
\hline $\operatorname{ADF}(4)$ & -2.3271 & 33.8357 & 26.8357 & 24.5990 & 27.0428 \\
\hline
\end{tabular}

95\% critical value for the augmented Dickey-Fuller statistic $=-3.7921$

LL = Maximized log-likelihood AIC = Akaike Information Criterion

$\mathrm{SBC}=$ Schwarz Bayesian Criterion $\quad \mathrm{HQC}=$ Hannan-Quinn Criterion

unit root tests for variable DDLPPP

The Dickey-Fuller regressions include an intercept but not a trend 
13 observations used in the estimation of all ADF regressions.

Sample period from 1999 to 2011



95\% critical value for the augmented Dickey-Fuller statistic $=-3.1223$

$\mathrm{LL}=$ Maximized log-likelihood AIC = Akaike Information Criterion

$\mathrm{SBC}=$ Schwarz Bayesian Criterion $\quad \mathrm{HQC}=$ Hannan-Quinn Criterion

Unit root tests for variable DDLPPP

The Dickey-Fuller regressions include an intercept and a linear trend

13 observations used in the estimation of all ADF regressions.

Sample period from 1999 to 2011




95\% critical value for the augmented Dickey-Fuller statistic $=-3.8288$
LL = Maximized log-likelihood
AIC = Akaike Information Criterion
$\mathrm{SBC}=$ Schwarz Bayesian Criterion
$\mathrm{HQC}=$ Hannan-Quinn Criterion

Examining the level of integration of ER
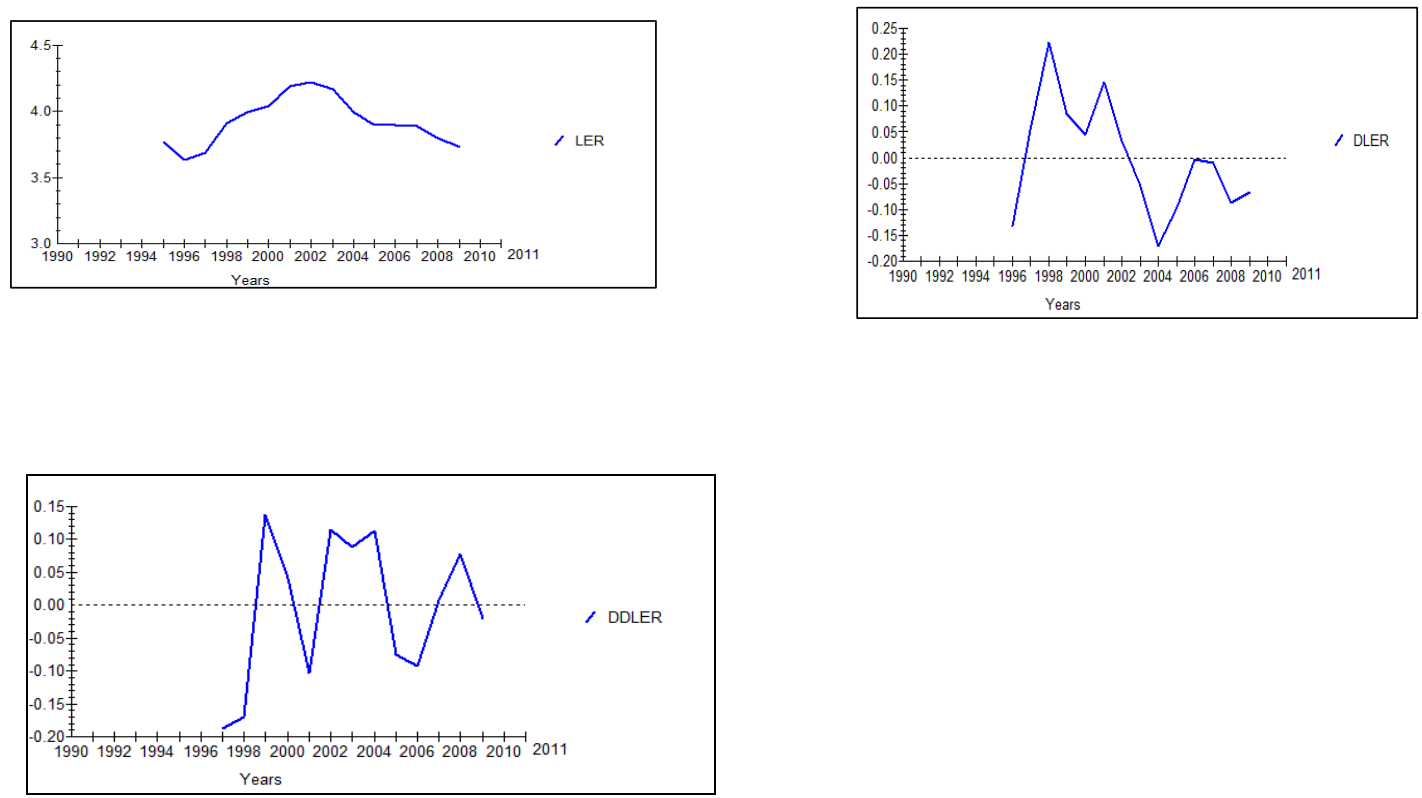
Unit root testing for LER and DLER



Unit root tests for variable DLER

The Dickey-Fuller regressions include an intercept but not a trend

9 observations used in the estimation of all ADF regressions.

Sample period from 2001 to 2009

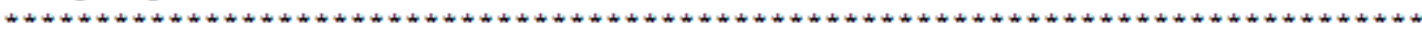

Test Statistic II AIC SBC HQC

$\begin{array}{lllllll}\text { DF } & -1.5655 & 10.8647 & 8.8647 & 8.6675 & 9.2903\end{array}$

$\begin{array}{llllll}\mathrm{ADF}(1) & -1.6465 & 11.1942 & 8.1942 & 7.8983 & 8.8326\end{array}$

$\begin{array}{lllllll}\mathrm{ADF}(2) & -1.3428 & 12.1052 & 8.1052 & 7.7108 & 8.9564\end{array}$

$\begin{array}{llllll}\mathrm{ADF}(3) & -1.2356 & 12.1842 & 7.1842 & 6.6911 & 8.2482\end{array}$

$\mathrm{ADF}(4) \quad-1.3352 \quad 12.8284 \quad 6.8284 \quad 6.2367 \quad 8.1052$

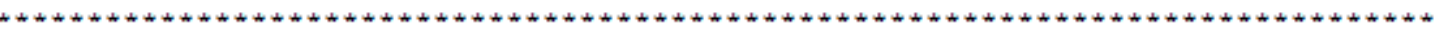

958 critical value for the augmented Dickey-Fuller statistic $=-3.2698$

LL = Maximized log-likelihood AIC = Akaike Information Criterion

$\mathrm{SBC}=$ Schwarz Bayesian Criterion HQC = Hannan-Quinn Criterion

Unit root tests for variable DLER

The Dickey-Fuller regressions include an intercept and a linear trend

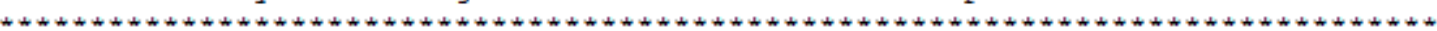

9 observations used in the estimation of all ADF regressions.

Sample period from 2001 to 2009

\begin{tabular}{|c|c|c|c|c|c|}
\hline & Test Statistic & LL & AIC & SBC & $\mathrm{HQC}$ \\
\hline $\mathrm{DF}$ & -1.6463 & 11.2184 & 8.2184 & 7.9225 & 8.8568 \\
\hline $\mathrm{ADF}(1)$ & -1.9597 & 12.1092 & 8.1092 & 7.7147 & 8.9604 \\
\hline $\operatorname{ADF}(2)$ & -.96081 & 12.2432 & 7.2432 & 6.7501 & 8.3072 \\
\hline $\operatorname{ADF}(3)$ & -1.1140 & 12.9075 & 6.9075 & 6.3158 & 8.1843 \\
\hline $\operatorname{ADF}(4)$ & -1.8433 & 15.8901 & 8.8901 & 8.1999 & 10.3798 \\
\hline \multicolumn{6}{|c|}{ 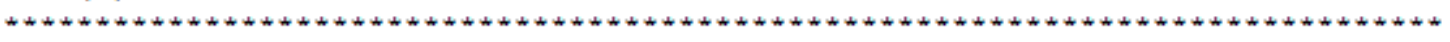 } \\
\hline \multirow{2}{*}{\multicolumn{6}{|c|}{$\begin{array}{l}958 \text { critical value for the augmented Dickey-Fuller statistic }=-4.0816 \\
\text { LL = Maximized log-likelihood AIC = Akaike Information Criterion }\end{array}$}} \\
\hline & & & & & \\
\hline \multicolumn{3}{|c|}{$\mathrm{SBC}=$ Schwarz Bayesian Criterion } & $=$ Hann & \multicolumn{2}{|c|}{$\begin{array}{l}\text { mation criterion } \\
\text { Criterion }\end{array}$} \\
\hline
\end{tabular}




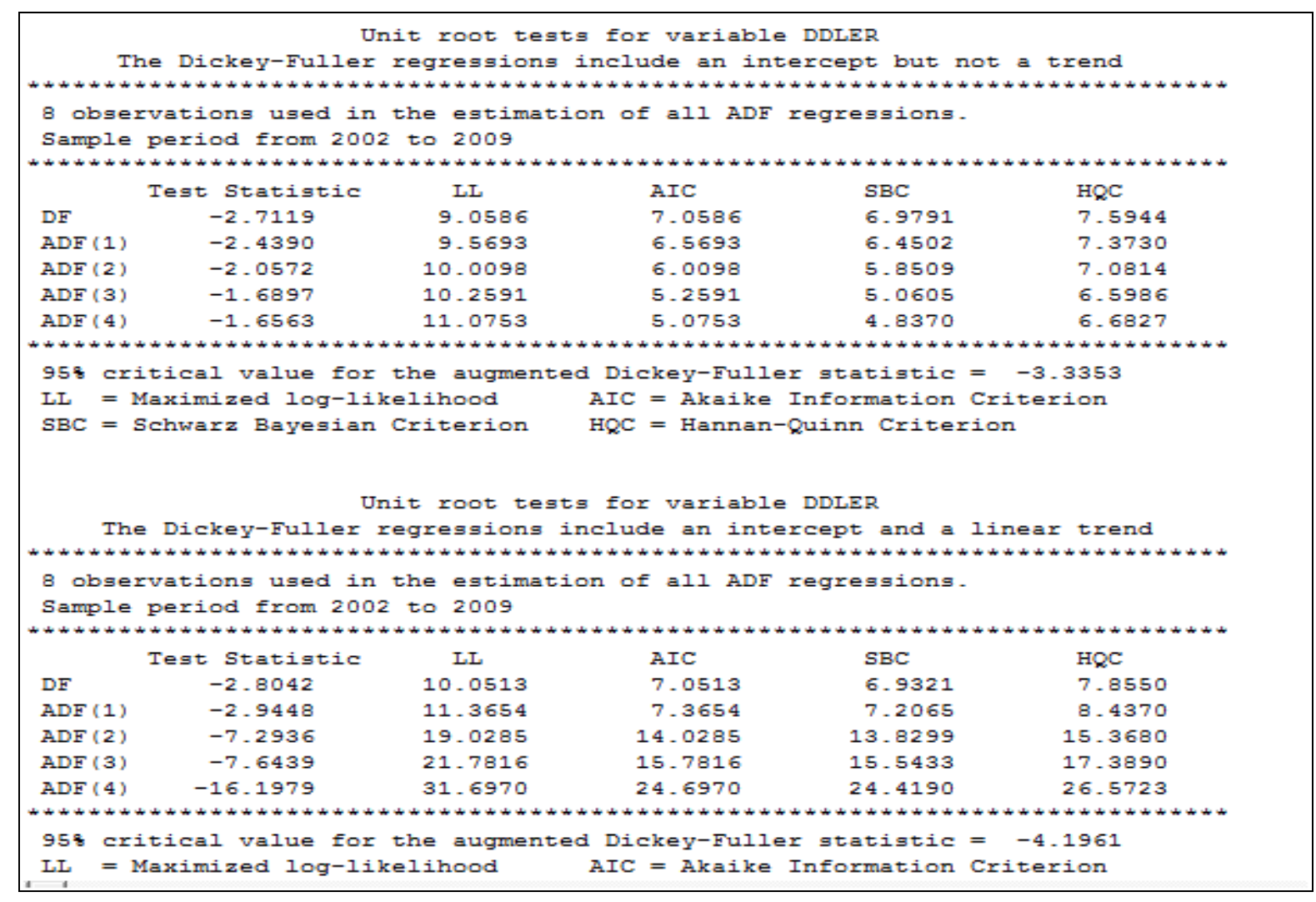

\section{Appendix 3}

\section{ENGLE GRANGER CO-INTEGRATION METHOD}

\section{Ordinary Least Squares Estimation}

Dependent variable is DLER

14 observations used for estimation from 1996 to 2009

\begin{tabular}{|c|c|c|c|}
\hline Regressor & Coefficient & Standard Error & T-Ratio[Prob] \\
\hline C & .0086514 & .036380 & $.23781[.816]$ \\
\hline DLPPP & -.41005 & .76646 & $-.53499[.602]$ \\
\hline \multicolumn{4}{|c|}{ 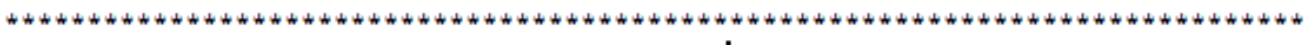 } \\
\hline R-Squared & .023295 & $\mathrm{R}-\mathrm{B}$ |r-Squared & -.058097 \\
\hline S.E. of Regression & .11237 & \multirow{2}{*}{$\begin{array}{l}\text { F-stat. } \quad F(1,12) \\
\text { S.D. of Dependent Variable }\end{array}$} & $.28621[.602]$ \\
\hline Mean of Dependent Variab & ble -.0023328 & & .10924 \\
\hline Residual Sum of Squares & .15153 & Equation Log-likelihood & 11.8171 \\
\hline Akaike Info. Criterion & 9.8171 & \multirow[t]{2}{*}{ Schwarz Bayesian Criterion } & \multirow[t]{2}{*}{9.1781} \\
\hline Dw-statistic & .96300 & & \\
\hline
\end{tabular}




\begin{tabular}{|c|c|c|c|c|c|}
\hline \multicolumn{6}{|c|}{ Unit root tests for residuals } \\
\hline \multicolumn{6}{|c|}{ 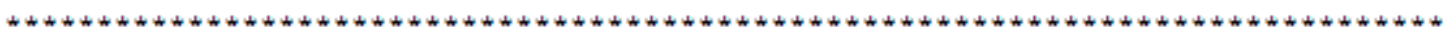 } \\
\hline \multicolumn{6}{|c|}{ Based on OLS regression of DLER on: } \\
\hline \multicolumn{6}{|c|}{ C $\quad$ DLPPP } \\
\hline \multicolumn{6}{|c|}{14 observations used for estimation from 1997 to 2010} \\
\hline \multicolumn{6}{|c|}{ 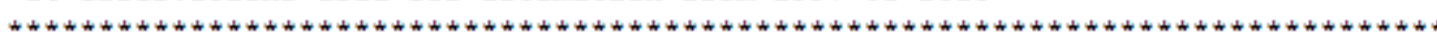 } \\
\hline & Test Statistic & LL & AIC & $\mathrm{SBC}$ & HQC \\
\hline $\mathrm{DF}$ & -1.4920 & 9.8993 & 8.8993 & 8.8007 & 9.1121 \\
\hline $\mathrm{ADF}(1)$ & -1.6077 & 10.2100 & 8.2100 & 8.0127 & 8.6356 \\
\hline $\mathrm{ADF}(2)$ & -1.2578 & 10.4964 & 7.4964 & 7.2006 & 8.1348 \\
\hline $\mathrm{ADF}(3)$ & -1.2502 & 10.6675 & 6.6675 & 6.2731 & 7.5187 \\
\hline $\mathrm{ADF}(4)$ & -1.3010 & 11.0347 & 6.0347 & 5.5416 & 7.0987 \\
\hline \multicolumn{6}{|c|}{ 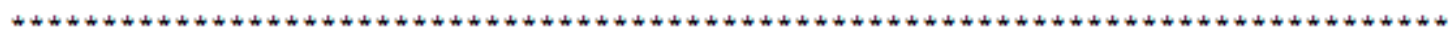 } \\
\hline \multirow{4}{*}{\multicolumn{6}{|c|}{$\begin{array}{l}958 \text { critical value for the Dickey-Fuller statistic }=-4.1109 \\
\text { LL = Maximized log-likelihood } \\
\text { SBC = Schwarz Bayesian Criterion }\end{array}$}} \\
\hline & & & & & \\
\hline & & & & & \\
\hline & & & & & \\
\hline
\end{tabular}

Unit root tests for residuals

Based on OLS regression of DLER on:

C DLPPP

14 observations used for estimation from 1996 to 2009

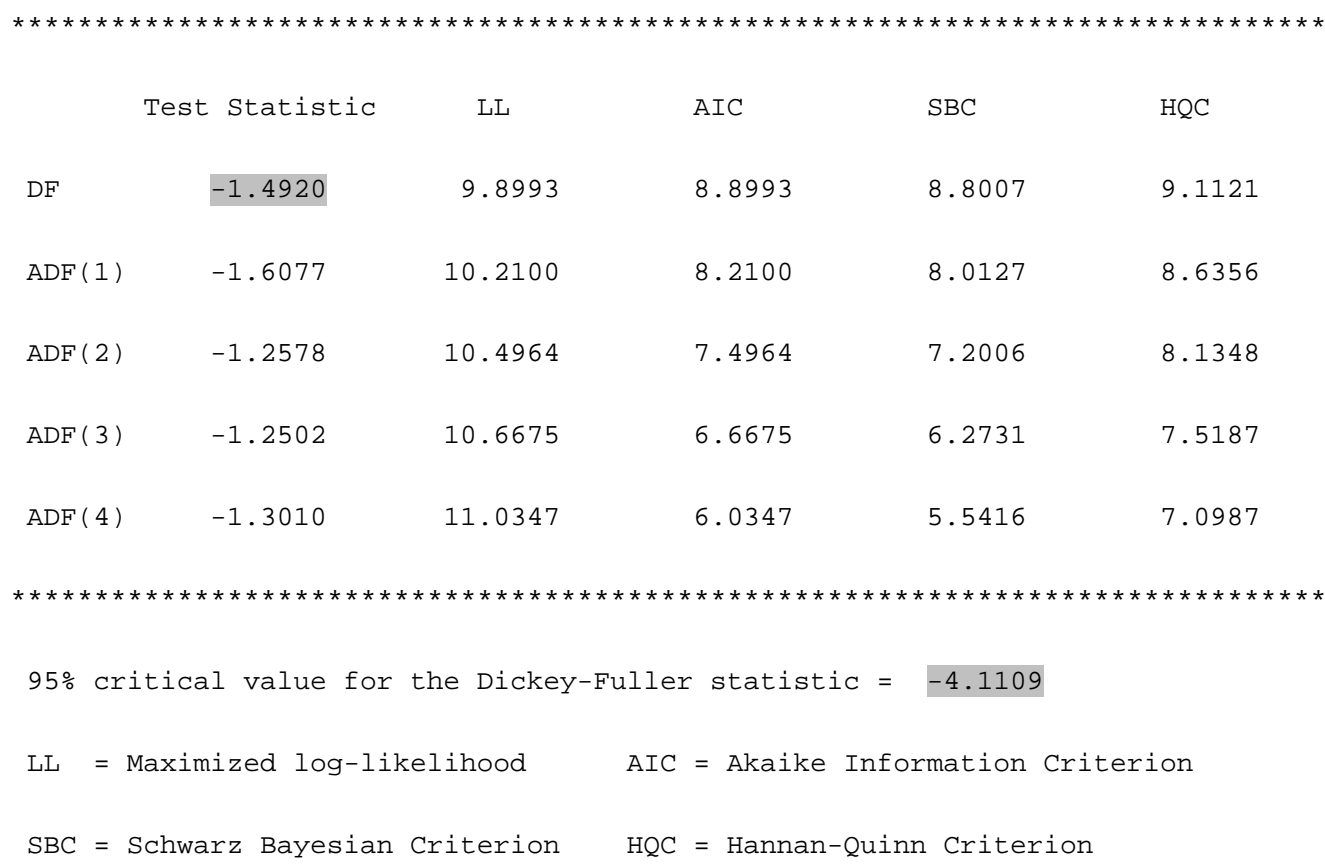




\section{Appendix 4}

\section{THE ERROR CORRECTION MODEL}
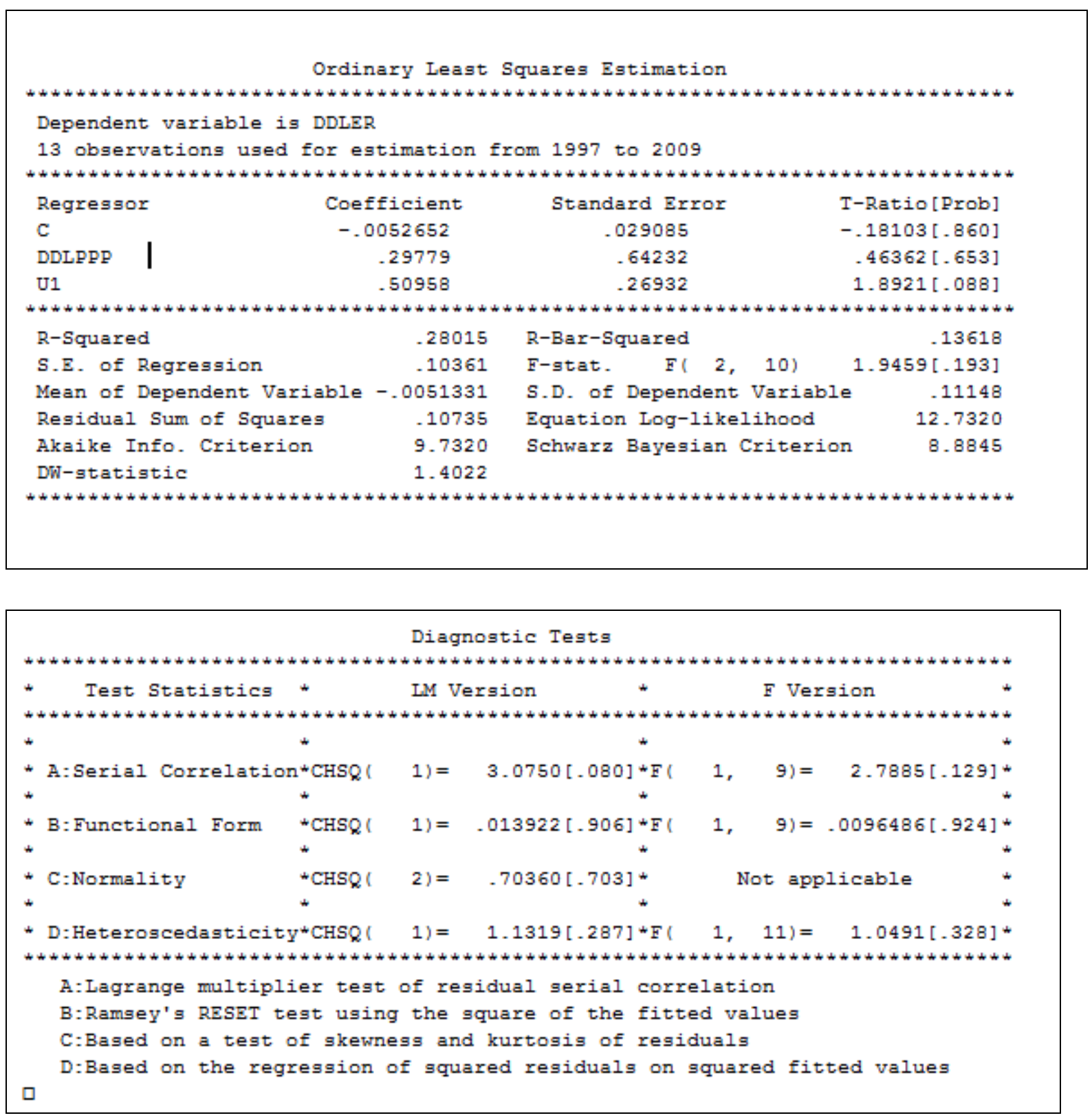

\section{References}

1. Besimi F., Pugh G. and N. Adnett, (Jan 2006), The Monetary Transmission Mechanism in Macedonia: Implications for Monetary Policy', , Working Paper 02-2006, Centre for Research on Emerging Economies, IESR, Staffordshire University, UK, 
2. Bogoev, J.,Terzijan, B.S., Égert,B., Petrovska, M.(2008), Real Exchange Rate Dynamics in Macedonia: Old Wisdoms and New Insights, Economics: The OpenAccess, Open-Assessment E-Journal Vol. 2, 2008-18

3. Borsic, Beko, Kavker, (2008), INVESTIGATING PURCHASING POWER PARITY IN CENTRAL AND EASTERN EUROPEAN COUNTRIES: A PANEL DATA APPROACH, University of Maribor, Faculty of Economics and Business

4. Feenstra, C.Roberts, (2004), Advanced international trade: theory and evidence, Princeton University Press

5. Krugman, R.Paul, Obstfeld, Maurice (2009), International economics: Theory and Policy ,Pearson Addison-Wesley

6. Madura, Jeff, (2009), International Financial Management, Cengage Learning, Tenth edition

7. Manzur, M., Chan, F.,(2010), Exchange rate volatility and purchasing power parity, The International Journal of Banking and Finance, Vol. 7. Number 1: 2010: 99-118

8. Obstfeld, Maurice, Rogoff,S.,Kenneth,(1998), Foundations of international macroeconomics, The MIT Press, London, England

9. Rogoff,S.,Kenneth, Husain,M.,Aasin,Mody Asholka, Brooks, Robin, Oomes, Nienke, (2004), Evolution and performance of exchange rate regimes, International Monetary Fund, Washington

10. The World Bank database

11. World Economic Outlook (WEO) database 